\title{
EFEKTIVITAS PEMBERIAN NANOPARTIKEL EKSTRAK DAUN JUWET \\ (Syzygium cumini) SEBAGAI ADJUVANT TERAPI TERHADAP \\ GAMBARANHISTOPATOLOGI PULMO MENCIT (Mus musculus) YANG DIINFEKSI Plasmodium bhergei
}

\section{EFFECTIVENESS OF GIVING JUWET LEAF EXTRACT NANOPARTICLES (Syzygium cumini) AS AN ADJUVANT OF THERAPY TOWARDS HISTOPATOLOGICALIMAGES OF PULMO MENCIT (Mus musculus) THAT IS INFECTED Plasmodium bhergei}

\author{
Zerlinda Dyah Ayu 1), Lilik Maslachah 2), Koesnoto Supranianondo 2), \\ Endang Suprihati 2), Hani Plumeriastuti 2), Rahmi Sugihartuti 2) \\ 1) Mahasiswa, 2) Dosen \\ Fakultas Kedokteran Hewan Universitas Airlangga \\ Kampus C UNAIR, Jl. Mulyorejo-Surabaya 60115 \\ Telp. 031-5992785, Fax. 031-5993015 \\ Email: jbmvunair@gmail.com
}

\begin{abstract}
The purpose of this study was to learn how to use juwet nanoparticle leaf extract (Syzygium cumini) as an adjunct therapy in pulmonary histopathological mice (Mus musculus) supported by Plasmodium berghei. This study used 30 rats divided into six groups consisting of K0 (disagree without agreement), P1 (fight without agreement), P2 (fight and dispute with chloroquine), P3 (fight and talk with juwet leaf extract), P4 (useful and useful with juwet leaf extract)) and P5 (extracts and combinations given with chloropine and juwet leaf extract nanoparticles) protected by 1x105 in $0.2 \mathrm{ml}$ of Plasmodium berghei. Data were analyzed by Kruskal Wallis using SPSS and continued with the Mann-Whitney test. The results of this study showed that there were significant differences $(\mathrm{p}<0.05)$ between P2 and P5, but did not show a significant difference $(\mathrm{p}>$ 0.05) with P1, P3 and P4. Based on this study, can be witnessed by juwet nanoparticles (Syzygium Cumini) additional therapeutic leaf extract which is expected to reduce pulmonary damage (hemmoragi, alveolar congestion, edema, hemosiderin) mice (Mus musculus) infected with Plasmodium berghei.
\end{abstract}

Key words: Syzygium cumini, Nanoparticle, Adjuvant therapy, Pulmonary, Plasmodium berghei

\section{PENDAHULUAN}

Malaria disebabkan oleh parasit genus plasmodium dan merupakan salah satu penyakit infeksi yang ditemukan di daerah tropik dan subtropik. Penyakit infeksi ini ditularkan oleh nyamuk Anopheles sp. (Wiser, 2011). Infeksi Plasmodium sering menyebabkan komplikasi pada beberapa organ, salah satunya terjadi pada pulmo. Pada organ tersebut terjadi anoksia jaringan karena adanya kelainan di mikrovaskuler, di dalam pembuluh kapiler terjadi sekuestrasi eritrosit yang terinfeksi parasit (Husna dan Prasetyo, 2016). Infeksi Plasmodium dapat meningkatkan radikal bebas dan aktivasi sel inflamasi yang menghasilkan reactive oxygen species (ROS) berlebih (Harlev, et al., 2015). Radikal bebas merupakan molekul yang reaktif dan dapat menimbulkan kerusakan jaringan, terutama sel endotel, jika hal ini terjadi pada endotel pulmo dapat menyebabkan gejala edema pulmo yang merupakan salah satu komplikasi penyakit malaria (Fitri, dkk., 2013; Mahzar, et al., 2016).

Hingga saat ini pengobatan penyakit malaria menggunakan obat klorokuin yang merupakann golongan 4 
preparat aminokuinolin. A Klorokuin bekerja pada tahap siklus intraeritrositik selama parasit aktif mendegradasi hemoglobin (Parhizgar and Tahghighi, 2017). Infeksi plasmodium dapat berakibat fatal karena dapat menyebabkan komplikasi malaria berat, oleh karena itu dibutuhkannya terapi adjuvan. Terapi adjuvan merupakan bahan tambahan pada suatu obat, agar menambah daya kerja komponen utamanya untuk memaksimalkan efektifitasnya yang dapat mencegah dan menghambat timbulnya komplikasi yang lebih berat, salah satunya adalah dengan pemberian antioksidan (Hiben et al., 2016 Tumbuhan juwet (Syzygium cumini) salah satu tumbuhan yang memiliki khasiat sebagai antioksidan. Ekstrak daun juwet mengandung senyawa alkaloid, fenol, flavonoid, tannin, minyak atsiri sebagai metabolit sekunder (Sudarmi, dkk.,2017). Kurangnya permeabilitas dalam menembus berrier absorbsi dan rendahnya kecepatan dissolusi pada bahan alam menyebabkan kurangnya bioevailabilitas sehingga kerja obat tidak bekerja secara maksimal karena senyawa bioaktif kurang memberikan efek farmakologis secara optimal (Ningrum, dkk.,2017).

\section{MATERI DAN METIODE PENELITIAN}

\section{Tempat dan Waktu Penelitian}

Penelitian ini dilakukan di beberapa laboratorium yang berbeda. Pengeringan dan penggilingan daun juwet dilakukan di Laboratorium Pakan Ternak Fakultas Kedokteran Hewan Universitas Airlangga. Pembuatan ekstrak daun juwet dilakukan di Laboratorium Farmakologi Fakultas Kedokteran Hewan Universitas Airlangga. Pembuatan dan pemeriksaan sediaan histopatologi dilakukan di Laboratorium Patologi Veteriner Fakultas Kedokteran Hewan Universitas
Airlangga. Pembuatan sediaan nanopartikel ekstrak daun juwet dilakukan di Laboratorium Biomolekuler Fakultas Kedokteran Hewan Universitas Airlangga. Pemeriksaan ukuran sediaan nanopartikel dilakukan di Fakultas Teknik Mesin Institut Teknologi Sepuluh November Surabaya. Pembuatan sediaan obat dilakukan di Laboratorium Ilmu Farmasi Veteriner Fakultas Kedokteran Hewan Universitas Airlangga. Pemeliharaan serta pemberian perlakuan mencit dilakukan di Kandang Hewan Coba Universitas Airlangga Surabaya. Penelitian ini dilakukan pada bulan Juli 2018 sampai November 2018.

\section{Alat dan Bahan}

Peralatan penelitian yang digunakan adalah kandang hewan coba beserta penutup kawat, sekat, tempat makan dan minum mencit, kertas undian, thermometer, spuit tuberkulin, sonde mencit, mikro pipet, mikrotube $1,5 \mathrm{ml}$, pipet pasteur, vacutainer, mesin sentrifuge, Improved Neubauer Counting Chamber, mesin penggiling, blender kering, alat rotary evaporator bath, baskom, sendok, toples besar, magnetic stirrer, sonikator, gelas ukur $(250 \mathrm{ml}$ dan $100 \mathrm{ml})$, gelas beaker $(500 \mathrm{ml}$ dan $200 \mathrm{ml})$, penjepit kayu, alumunium foil, tabung reaksi, almari pendingin, alat freeze dryer, neraca analitik, sudip, alat scanning electron microscope (SEM), cawan penguap, mortar, stamper, batang pengaduk, spatel, kertas perkamen, kertas label, botol obat, petri dish, sarung tangan latek, masker, papan preparasi, jarum pentul, alat bedah minor, pot sampel, alat mikrotom, object glass, cover glass, kotak sediaan histopatologi, staining jar, counter, dan mikroskop.

Penelitian ini menggunakan daun juwet (Syzygium cumini), ethanol Pro Analisis (PA) 96\%, NaTTP (Natrium Tripolyphosphate), kitosan, larutan buffer 
asetat 2\% dengan $\mathrm{pH} 4$, es serut, aquades, CMC-Na, klorokuin, mencit (Mus musculus), pakan mencit berupa pellet ayam, serbuk kayu, pewarna asam sitrat, Phosphate Buffer Saline (PBS), elsevier, serbuk EDTA, Plasmodium berghei strain ANKA dari LPT bagian laboratorium malaria, cat giemsa, oil emersi, aquades steril, methanol 96\%, alkohol $70 \%$, ketamin 10\%, hepar yang terinfeksi Plasmodium berghei, formalin $10 \%$, pewarna Haematocylin Eosin (HE), larutan FFA (formaldehyde: acetic acid: alcohol), larutan $x y$ lol, larutan alkohol bertingkat $(70 \%, 80 \%, 90 \%, 95 \%)$, alkohol absolut, cairan parafin, albumin, dan gliserin.

\section{Prosedur Penelitian}

Pada penelitian ini digunakan mencit (Mus musculus) sebagai hewan coba sebanyak 30 ekor yang dibagi menjadi 6 perlakuan yaitu K0 yang tidak diinfeksi dan diberi pelarut obat, P1 yang diinfeksi dan diberi pelarut obat, P2 yang diinfeksi dan diberi klorokuin, P3 yang diinfeksi dan diterapi ekstrak daun juwet, P4 yang diinfeksi dan diterapi nanopartikel ekstrak daun juwet, P5 yang diinfeksi dan diterapi klorokuin serta nanopartikel ekstrak daun juwet. Terapi dilakukan selama empat hari, 24 jam pasca infeksi. Pada hari ke-15 pasca infeksi, mencit dieutanasi dan organ pulmo dikoleksi untuk dibuat preparat histopatologi.

\section{HASIL DAN PEMBAHASAN}

Pengamatan histopatologi pulmo mencit antara lain edema, hemmoragi, kongesti alveolar dan hemosiderin. Skoring histopatologi pulmo dengan cara melihat preparat di bawah mikroskop dengan perbesaran 400x yaitu lensa objektif 40x dan lensa okuler 10x yang diamati pada 5 lapangan pandang setiap preparat. Sediaan histopatologi didapatkan dari organ hepar mencit yang diinfeksi dengan Plasmodium berghei beserta perlakuan tiap kelompok dan dibuat sediaan histopatologi menggunakan pewarnaan Haematoxylin Eosin (HE). Perubahan histopatologi diamati menggunakan mikroskop Olympus dengan fasilitas pendukung Optilab Viewer.

Hasil pengamatan dinilai berdasarkan tabel skoring histopatologi (Hansel dan Barnes 2004), kemudian di analisis menggunakan Kruskal-Wallis test. Semua pengamatan pada penelitian ini menunjukkan perbedaan yang signifikan $(p<0.05)$ sehingga dilanjutkan dengan analisis Mann-Whitney $U$ test untuk melihat perbedaan pada setiap kelompok perlakuan. Hasil analisis pada Tabel 4.1.1 dapat dilihat bahwa perubahan histopatologi pulmo mencit yang mengalami edema pulmo paling parah pada perlakuan P1 dan paling ringan pada perlakuan K0. Perlakuan K0 dan P5 menyebabkan perbedaan yang signifikan $(\mathrm{P}<0,05)$. Perlakuan P5 dan P2 menyebabkan perbedaan yang signifikan $(\mathrm{P}<0,05)$. Perlakuan P2 dan P3 menyebabkan perbedaan yang signifikan $\quad(\mathrm{P}<0,05) \quad$ sedangkan perlakuan P3 dan P4 tidak menyebabkan perberbedaan yang signifikan $(\mathrm{P}>0,05)$. Perlakuan P3 dan P4 menyebabkan perubahan yang signifikan $(\mathrm{P}<0,05)$ dengan Perlakuan P1.

Perubahan histopatologi pulmo mencit yang mengalami hemosiderin pulmo menyebabkan perbedaan yang signifikan $(\mathrm{P}<0,05)$ antara perlakuan $\mathrm{K} 0$ dan P5. Perlakuan P5 dan perlakuan P1. P2, P3, dan P4 menyebabkan perbedaan yang signifikan $(\mathrm{P}<0,05)$. Sedangkan perlakuan P1. P2, P3, dan P4 tidak menyebabkan perberbedaan yang signifikan $\quad(\mathrm{P}>0,05)$ Kelompok perlakuan K0 dan P5 terlihat terjadi penurunan hemosiderin pulmo, dibandingkan kelompok perlakuan P1. P2, P3, dan P4 yang tidak menunjukkan perbedaan yang signifikan $(\mathrm{P}<0,05)$. 
Perubahan histopatologi pulmo mencit mengalami penurunan kerusakan kongesti alveolar pada kelompok perlakuan $\mathrm{K} 0$ dan P5 tidak menyebabkan perbedaan yang signifikan $(\mathrm{P}<0,05)$. Perlakuan $\mathrm{K} 0$ dan P5 menyebabkan perbedaan yang signifikan $(\mathrm{P}<0,05)$ dengan Perlakuan $\mathrm{P} 2$ dan P3. Perlakuan P2 dan P3 tidak menyebabkan perberbedaan yang signifikan $(\mathrm{P}>0,05)$. Perlakuan P2 dan P3 menyebabkan perbedaan yang signifikan $(\mathrm{P}<0,05)$ dengan perlakuan $\mathrm{P} 1$ dan P4. Perlakuan P1 dan P4 tidak menyebabkan perberbedaan yang signifikan $(\mathrm{P}>0,05)$.
Perubahan histopatologi pulmo menunjukkan adanya hemoraghi pada kelompok perlakuan $\mathrm{K} 0$ paling rendah dan paling tinggi pada kelompok perlakuan P3. Kelompok perlakuan K0 dan P5 menyebabkan perbedaan yang signifikan $(\mathrm{P}<0,05)$. Perlakuan P5 menyebabkan perbedaan yang signifikan $(P<0,05)$ dengan perlakuan P2. Perlakuan P2 menyebabkan perbedaan yang signifikan $(\mathrm{P}<0,05)$ dengan P1 dan P4. Sedangkan perlakuan P1 dan P4 tidak menyebabkan perberbedaan yang signifikan $(\mathrm{P}>0,05)$. Perlakuan P1 dan P4 menyebabkan perbedaan yang signifikan.

Tabel 4.1. Hasil Pemeriksan histopatologi pulmo mencit (Mus musculus) pada kelompok kontrol dan kelompok perlakuan

\begin{tabular}{|c|c|c|c|c|}
\hline \multirow[b]{2}{*}{ Perlakuan } & \multicolumn{4}{|c|}{ Perubahan Mean \pm SD } \\
\hline & Edema & Hemosiderin & $\begin{array}{l}\text { Kongest1 } \\
\text { Alveolar }\end{array}$ & Hemoraghi \\
\hline K0 & $0,12^{a} \pm 0,06$ & $0,07 a \pm 0,54$ & $0,52^{a} \pm 0,06$ & $0,38^{a} \pm 0,06$ \\
\hline P1 & $2,48^{e} \pm 0,03$ & $2,30^{c} \pm 0,11$ & $2,58^{c} \pm 0,19$ & $2,40^{d} \pm 0,12$ \\
\hline P2 & $1,50^{c} \pm 0,08$ & $2,08 c \pm 0,11$ & $1,95^{b} \pm 0,06$ & $1,75^{c} \pm 0,17$ \\
\hline P3 & $2,37 \mathrm{~d} \pm 0,03$ & $2,13 c \pm 0,21$ & $2,68^{b} \pm 0,03$ & $2,70 \mathrm{e} \pm 0,15$ \\
\hline P4 & $2,35^{d} \pm 0,14$ & $2,13 c \pm 0,18$ & $2,35 \div 0,03$ & $2,27 d \pm 0,12$ \\
\hline P5 & $0,52^{\mathrm{b}} \pm 0,96$ & $0,45^{b} \pm 0,64$ & $0,45^{a} \pm 0,33$ & $0,68^{b} \pm 0,25$ \\
\hline
\end{tabular}



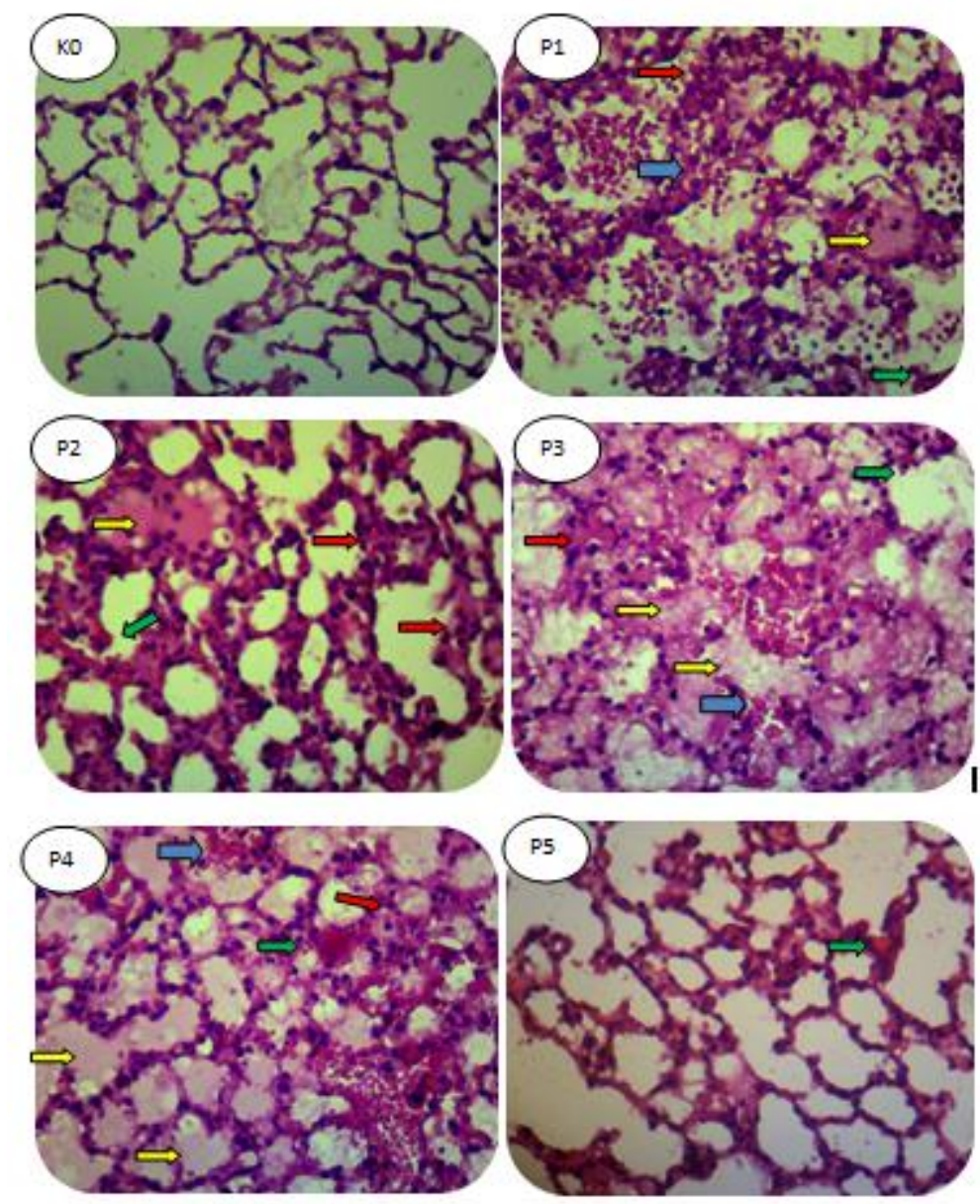

Gambar 4.1 Gambaran histopatologi paru-paru mencit yang diinfeksi Plasmodium bergh̀ei (pembesaran 400x, H\&E). Hemmoragi (panah biru), Kongesti Alveolar (panah merah). Edema (panah kuning). Hemosiderin (panah hijau)

Hasil ini menunjukkan bahwa perlakuan 1 (P1) yang diinfeksi Plasmodium berghei tanpa pemberian terapi obat menyebabkan kerusakan organ pulmo yaitu edema, kongesti alveolar, hemosiderin, hemmoragi yang sangat meningkat. Edema terjadi karena aliran pembuluh darah vena penuh sehingga tekanan hidrostatik vaskuler dan tekanan osmotik meningkat, dan terjadi transudasi. Sehingga terlihat cairan fibrin yang berwarna pink homogen di lumen alveoli.

Perlakuan yang yang diterapi klorokuin terlihat hanya sedikit penurunan kerusakan jaringan. Hal ini terjadi karena klorokuin hanya efektif terhadap parasit dalam fase eritrosit, tidak efektif terhadap parasit di jaringan. Akan tetapi terlihat sedikit penurunan pada edema dan hemmoragi, hal tersebut diduga karena pada pemberian klorokuin terjadi kematian parasit yang berakibat pada penurunan jumlah parasit yang menginfeksi eritrosit sehingga jumlah eritrosit yang mengandung hemoglobin untuk suplai oksigen pada sel-sel dan jaringan masih mencukupi.

Perlakuan yang hanya diterapi ekstra daun juwet dan nanopartikel ekstrak daun juwet juga tidak menunjukkan perbedaan yang signifikan dalam penurunan kerusakan organ pulmo yaitu hemmoragi, kongesti alveolar, edema, hemosiderin. Penelitian 
ini pun juga menunjukkan bahwa mencit yang diterapi menggunakan nanopartikel ekstrak daun juwet juga mengalami hemmoragi, kongesti alveolar, edema, hemosiderin 0 lebih parah dibandingkan dengan mencit yang diterapi menggunakan ekstrak daun juwet. Hal tersebut kemungkinan dikarenakan ukuran partikel ekstrak daun juwet dalam ukuran nano dapat meningkatkan kelarutan serta absorbsi obat dalam saluran cerna, sehingga bahan aktif yang sampai pada pulmo untuk dibentuk menjadi metabolit aktifnya lebih banyak (Bilia, et al., 2014). Pemberian ekstrak daun juwet dalam ukuran nano mengakibatkan peningkatan luas permukaan. Hal tersebut mengakibatkan peningkatan kontak dengan permukaan epitel yang akan menyebabkan absorbsi partikel lebih banyak (Pridge, et al., 2015).

Penggunaan antioksidan yang terkandung dalam nanopartikel ekstrak kasar daun juwet sebagai terapi ajuvan yang dikombinasi dengan klorokuin dianggap penting untuk mempercepat proses kesembuhan serta mengurangi kerusakan jaringan normal yang lebih berat melalui mekanisme kerja obat klorokuin yang membuat intake makanan Plasmodium terganggu. Mekanisme kerja obat klorokuin tersebut didukung oleh antioksidan yang terkandung dalam nanopartikel ekstrak daun juwet melalui mekanisme penangkal efek radikal bebas dengan cara menghambat peroksidasi lipid sehingga dinding sel eritrosit lebih kuat dan tidak mudah ruptur. Sehingga hal tersebut dapat mengurangi komplikasi yang lebih berat terkait penyakit malaria (Varo, et al., 2018).

Perlakuan yang dikombinasi antara klorokuin dan nanopartikel ekstrak daun juwet menunjukkan hasil yang cukup bagus karena penggunaan antioksidan sebagai terapi adjuvant dengan tekhnologi nanopartikel yang dikombinasi dengan antimalaria dianggap penting untuk mempercepat proses kesembuhan serta memperbaiki kerusakan sel atau jaringan yang lebih berat pada organ pulmo yaitu hemmoragi, kongesti alveolar, edema, hemosiderin. Hal ini terjadi karena hambatan pembentukan oksigen reaktif. Mencit yang terinfeksi Plasmodium dan diterapi kombinasi menggunakan klorokuin serta nanopartikel ekstrak daun juwet menyebabkan pembentukan Reactive Oxygen Species (ROS) menjadi terhambat (Shankara, et al, 2014 dan Azima, et al, 2013).

Aktivitas antioksidan pada daun juwet senyawa flavonoid dan polifenol. Senyawa ini dapat menyumbangkan satu atom hidrogen untuk dipasangkan dengan elektron radikal bebas yang tidak stabil yang bertujuan untuk menstabilkan radikal peroksidasi lipid yang mengakibatkan struktur membran sel menjadi normal kembali. Antioksidan penting dalam menunjang sistem imun dan menurunkan stres oksidatif. Flavonoid dapat menghambat sikloosigenase atau lipooksigenase dan menghambat akumulasi leukosit yang berfungsi sebagai antiinflamasi. Siklooksigenase adalah enzim yang berperan dalam pembentukan inflamasi dan rasa nyeri ketika terekspresi secara berlebihan (Ramya, et al., 2012; Marliyani, et al., 2014).

Selain ditunjang dengan adjuvant terapi, nanopartikel yang telah terbukti menjadi solusi secara tekhnologi untuk mengatasi keterbatasan seperti kecepatan dissolusi yang rendah, dengan kecilnya ukuran nanopartikel dapat meningkatkan luas permukaan, meningkatkan bioavailabilitas dari kelarutan yang kecil. Nanopartikel juga mampu menjadi penunjang adjuvant yang baik untuk penghantar obat ke target, memperpanjang efek obat di jaringan, membantu kelarutan obat di intravaskuler. Formulasi nanopartikel sangat membantu kinerja dari ekstrak daun juwet sebagai adjuvant terapi sehingga mengurangi kerusakan organ yang terjadi di pulmo, seperti 
hemosiderin, edema, kongesti alveolar dan hemmoragi (Oliveira et al., 2013; Kusuma, 2015). Pemberian Ekstrak daun juwet dan ekstrak nanopartikel daun juwet yang diberikan secara tunggal tidak menunjukkan hasil yang efektif karena rendahnya absorbsi dan ti.dak bisa menggati kerja dari obat utama (Terania., 2015). Maka dari itu pemberian ekstrak daun juwet dan ekstrak nanopartikel daun juwet harus di kombinasi dengan obat utama karena ekstrak daun juwet dan ekstrak nanopartikel daun juwet hanya sebagai adjuvan terapi.

\section{KESIMPULAN}

Berdasarkan penelitian yang telah dilakukan dapat disimpulkan bahwa pemberian nanopartikel ekstrak daun juwet (Syzygium cumini) sebagai terapi adjuvan dapat menurunkan perubahan histopatologik pulmo (hemmoragi, kongesti alveolar, edema, hemosiderin) mencit (Mus musculus) yang diinfeksi Plasmodium berghei. Pada pemberian pemberian ekstrak daun juwet dan ekstrak nanopartikel daun juwet yang diberikan secara tunggal tidak menunjukkan hasil yang efektif karena rendahnya absorbsi dan tidak bisa menggantikan kerja dari obat pertama.

\section{DAFTAR PUSTAKA}

Bilia, A.L., B. Isacchi, C. Righeschi, C. Guccione, M.C. Bergonzi. 2014. Flavonoids loaded in nanocarriers: an opportunity to increase oral bioavailability and bioefficacy. J. Food and Nutrition Sciences. 5: 1212-1227.
Fitri, L. E., Sardjono, T. W., Hermansyah, B., Candradikusuma, D., and BerensRiha N. 2013. Unusual Presentation of Vivax Malaria with Anaemia, Thrombocytopenia, Jaundice, Renal Disturbance, and Melena: A Report from Malang, a Nonendemic Area in Indonesia. Vol 4.

Harlev, A., A. Ashok, O.G. Sezgin, S. Amit, and S.P. Stefan. 2015. Smoking and Male Infertility: An Evidence-Based Review. World J. Mens Health. 33(3): 143-160.

Hiben, M. G., Sibhat, G. G., Fanta, B. S., Gebrezgi, H. D., Tesema S. B. 2016. Evaluation of Senna singueana leaf extract as an alternative or adjuvant therapy for malaria. V6.

Hiben, M.G., Sibhat, G.G., Tesema, S.B. and Fanta, B.S. 2016. Evaluation of Senna Singueana Leafe Extract as an Alternative or Adjuvant Therapy for Malaria.

Husna, M dan Prasetyo B.H. 2016. Aspek Serebral. Biomolekuler dan Update Terapi Malaria Serebral. Labboratorium Neurologi Fakutas Kedokteran Universita Brawijaya. Malang.

Kusuma, D.F.R. 2018. Efek Pemberian Ekstrak Etanol Daun Juwet (Syzygium Cumini) Sebagai Terapi Adjuvant Terhadap Jumlah Sel Mikroglia Pada Otak Mencit (Mus Musculus) Yang Diinfeksi Plasmodium berghei \{Skripsi\}. Fakultas Kedokteran Hewan. Universitas Airlangga. 
Marliani, L., Kusriani, H., dan Indah Sari, N. Aktivitas Antioksidan Daun dan Buah Jamblang (Syzygium cumini L.) Skeel. Sekolah tinggi Ilmu Farmasi Bandung. 2014.

Ningrum, L. P., N. Salim, dan U. Balqis. 2017. Pengaruh Ekstrak Daun Juwet (Syzygium cumini L) TerhadapHistopatologi Hepar Tikus Putih(Rattus norvegicus) Diabetes Melitus. J. JIMVET. 01(4) : 695-701.

Parhizgar, A.R. and A. Tahghighi. 2017. Introducing new antimalarial analouges of chloroquine and amodiaquine: a narrative review. Iran J. Med. Sci. 42(2): 115-128.

Pridge, E.M., F. Alexis, and O.C. Farokhzad. 2015. Polymeric nanoparticle drug delivery technologies for oral delivery applications. Exp. Opin. Drug Deliv. 12(9): 1459-1473.

Ramya, S., K. Neethirajan, and R. Jayakumararaj. 2012. Profile of bioactive compounds in Syzygium cumini- a review. J. of Pharmacy Research. 5(8): 45484553.

Ramya, S., Neethirajan, K., Jayakumararaj, R. (2012): Profile of bioactive compounds in Syzygium cumini. Journal of Pharmacy Research, 5(8),4548-4553
Ramya, S., Neethirajan, K., dan Jayakumara, R. 2012. Profile of Bioactive Compounds in Syzygium cumini : A Review. Journal of Pharmacy research. Vol. 5 (8) : 4548-4553

Shankara, R et al. Antioxidant activity of Syzygium cumini leaf gall extracts. BioImpacts. $4(2)$. http://bi.tbzmed.ac.ir. 2014. 101107.

Sudarmi, K., Darmayasa, I. B. G., Muksin, I. K. 2017. Uji Fitokimia Dan Daya Hambat Ekstrak Daun Juwet (Syzygium Cumini) Terhadap Pertumbuhan Escherichia Coli dan Staphylococcus Aureus ATCC. Vol 5. No 2.

Varo, R., V.M. Crowley, A. Sitoe, L. Madrid, L. Serghides, K.C. Kain, and Q. Bassat. 2018. Adjunctive Therap for Severe Malaria: A Review and Critical Apprasial. Malaria J. 17(47): 1-18.

Wiser, M. (2011). Plasmodium Species Infecting Humans. Human Plasmodium Species. Vol.15. 